\title{
Belgeselde Canlandırma ve Gerçekçilik Sorunu
}

\author{
Barıș Tolga Ekinci ${ }^{1}$
}

\begin{abstract}
Öz
Belgesel, gerçekliğe en yakın film türü olarak görülür. Belgeselde, gündelik yaşamın detayları gerçek-çekimlerle yeniden inşa edilir. Günümüzde, belgeseli diğer türlerden ayıran çizgiler bulanıklaşmaktadır. Nitekim belgesel adı alında kabul edilen pek çok filmde, gerçekçilik kavramı bir zorlama olarak yer almaktadır. Bu çalışmada, belgeselde gerçekçilik sorunu, melez yapılarla karşılaştırılarak incelenecektir. Bu bağlamda, belgesel ile canlandırma belgesel türü arasındaki ilişki, ele alınacaktır. Geleneksel belgesellerle kıyaslandığında, canlandırma belgeseller, tamamıyla gerçekdışı gözükebilir. Nitekim canlandırma belgeseller, gerçek-çekimlere ve fotoğraflara dayanmaz.
\end{abstract}

Bu bağlamda; Waltz with Bashir (2008), Is the Man Who Is Tall Happy?: An Animated Conversation with Noam Chomsky (2013) ve The Life and Mind of Mark DeFriest (2014) filmleri, tür eleştirisi yöntemiyle incelenecektir. Araştırmada, tür eleştirisine ilaveten, anket uygulaması yapılmış ve elde edilen bulgular analiz edilmiştir.

Anahtar kelimeler: Belgesel, Canlandırma Belgesel, Gerçekçilik, Melezlik, Tür.

\section{The Problem of Realism and Animation in Documentaries}

\begin{abstract}
Documentaries are considered as the closest genre to realism. The details of daily life are rebuilt with live-action in documentaries. Today, the lines that separate documentaries from other genres are fading. Hence, the concept of realism has been used as a constraint in many movies, which are considered as documentaries. In this study, the problem of realism in documentaries will be compared to the hybrid structures and examined. In this context, the relationship between documentary and animated documentary genre will be discussed. Compared to the traditional documentaries, the animated documentaries can be considered completely unreal. Indeed, animated documentaries are not based on live-actions and photographs.

Waltz with Bashir (2008), Is the Man Who Is Tall Happy?: An Animated Conversation with Noam Chomsky (2013) and The Life and Mind of Mark DeFriest (2014) movies will be examined in this context using genre criticism method. Furthermore, a questionnaire has been conducted and the results will be analysed in the study.
\end{abstract}

Keywords: Documentary, Animated Documentary, Realism, Hybridity, Genre.

1 Yrd. Doç. Dr. Beykent Üniversitesi, İletişim Fakültesi. 


\section{Giriș}

$\mathrm{S}$ inemanın, belgesel filmle başladığı düşünülür. Auguste ve Louis Lumière Kardeşler, on dokuzuncu yüzyıl sonundan, Birinci Dünya Savaşına dek yüzlerce film çekmiştir ve bu filmlerin neredeyse tamamı bir ya da birkaç sahneden oluşmaktadır. İlk filmler², belgesel tanımını karşılamasa da; önemli belge filmlerdir (Akbulut, 2012: 9-10). Ancak geleneksel belgeselin başlangıcı için bir tarih belirlemek gerekirse, Robert Joseph Flaherty'nin Kuzeyli Nanook ${ }^{3}$ (Nanook of the North 1922), filmi örnek gösterilebilir. Kuzeyli Nanook ${ }^{4}$, günümüzün yenilikçi ve ilerici sinemacıları tarafından kutsanan güçlü ve katıımcı sinemacılık öğelerini sergiler (Musser, 2008:117).

"Belgeselciler, her zaman için oyuncuların bakış açılarından düşünürler. Heykeltıraş ve ressamlar gibi içten dışarı dönük olarak düşünmek zorundadırlar. Kameranın hareket ve konumundan, çekimde, psikolojik tutumdan doğal oyuncunun zihninin yorumlanmasına kadar her şeyin göz önünde bulundurulması gerekir. Flaherty, bu yorumlama konusundaki en yetenekli yönetmendir" (Rotha, 2000: 122-124).

Nitekim film eleştirmenleri, her filmin hatta belgeselin bile, kurmaca yapılar içerdiğini belirtmektedirler. Çünkü her film kendi olanaklarını (hareketli görüntü ve sesler) içerir. Bir başka ifadeyle, filmlerde gerçek olaylar temsili yapılar kanalıyla yeniden inşa edilir. Belgeselin, kurmacadan daha gerçekçi olduğu düşünülebilir. Çünkü bazı filmlerde, belgesel ve kurmacanın birlikteliği, yeni anlatım dillerini de ortaya çıkarabilir. Örneğin, melez yapılar ve kurmaca için düşünülen canlandırma yöntemi, bu birlikteliklerden bazılarıdır. Canlandırma yöntemi sayesinde sanatçılar; görüntüleri, olayları ve durumları yeniden sorgulayabilirler. Bu dışavurumculuk ile gerçeklik arasındaki sınırların kaybolduğu anlamına da gelebilir. Ancak göstergeler, bu iddianın oldukça tartışmalı olduğunu ortaya koymaktadır. Örneğin, Thomas Austin, dünyaya bakışın belgesel türünde hiç olmadık biçimde sınırlayıcı klişeler yarattığına dikkat çekmektedir (Clarke, 2012: 122).

Çalışmada, melez bir tür olan "Canlandırma Belgesel" türü incelenecektir. Annabelle Honess Roe (2013), "Animated Documentary" isimli kitabında canlandırma belgesel fikrini; farklı dünyalara ait bireylerin evliliklerine benzetmektedir. Canlandırma belgesellerde yaratım süreci, boyama ya da heykeltıraşlık gibi işlemektedir. Bu izleyen açısından yorumlamayabilmeyi kolaylaştırmaktadır. Annabelle Honess Roe, bu iki zıt disiplinin kesiştiği sanatsal alanların da olduğunu ifade eder. Örneğin, canlandırma belgesel düşüncesi, Dünya'yı farklı bir gerçeklikten görme deneyimi olarak düşünülebilir. Nitekim pek çok canlandırma belgeselin gerçeklik savı, belgesel iddiasıyla karşılanmaktadır. Araştırmada, belgesel ve canlandırma belgesel türü ilişkisi,

2 Lumière Kardeşler'in Trenin Gara Girişi (orijinal ismi, Trenin Ciotat Garına Girişi'dir) (Arrival of a Train at La Ciotat, 1895) filmi, bu açıdan ilkler arasında yer alır. "İyi bir fotoğrafçı olan Louis Lumiere, bu kısa filmde, trenin hareketini diyagonal bir kompozisyon içinde görüntülemiş, çerçeveyi günlük yaşamın ayrıntılarıyla da zenginleştirmişti. Trenin karşıdan hızla gelişinin etkisi, kocaman şapkasıyla ilerleyen bir kadının görüntüsüyle tamamlanıyordu. Bu filmlerdeki gerçekçi yaklaşım, sonraki yıllarda Vertov'dan, Jean Renoir'a ve İtalyan yeni gerçekçilerine dek uzanacak bir eğilimin başlangıcı olmuştur" (Abisel, 2003: 34)

3 Filmin künyesi için bkz. http://www.imdb.com/title/tt0013427/?ref_=ttrel_rel_tt

4 Kuzeyli Nanook'ta, Robert Joseph Flaherty'nin kamerası çoğu durumda bir tripod üzerindedir. Filmde, gerçek kişiler, doğal hallerini objektif önünde yeniden sunmaktadır. Aynı dönemde, Dziga Vertov'un Rusya'daki çalışmaları ve Fransa'da Alberto Cavalcanti'nin Rien que les heures (1926) filmi ile İngiltere'de John Grierson'ın çalışmaları değerli örneklerdendir (Rotha, 2000: 52). 
sinemasal gerçekçilik kapsamında incelenecektir. Çalışmanın amacı, belgeselin gerçekçilik savı ile tasarım boyutunu karşılaştırarak, gelişen yeni belgesel arayışları irdelemektir. Bu bağlamda, örnek seçilen filmler, tür eleştirisi ve anket uygulamasıyla analiz edilecektir.

\section{Sinemada Gerçekçilik ve Kuramsal Çerçeve}

Sinema tarihinin başından beri, gerçekçilik sorunu, doğrudan ya da dolaylı olarak ele alınmıştır. Bu bağlamda, pek çok gerçeklik arayışı bulunmaktadır. Bu arayışlardan bazıları şu şekilde özetlenebilir: İngiliz Belgesel Hareketi ${ }^{5}$, Dziga Vertov' ${ }^{\prime}$ un Sine-Göz Manifestosu $^{7}$, Sinema-gerçek ${ }^{8}$ akımı (Cinema-verite), Dolaysız-sinema akımı ${ }^{9}$ (Directcinema), Yeni Gerçekçilik akımı ${ }^{10}$ (Neo-Realismo), Yeni Dalga akımı ${ }^{11}$ ve Dogma $95^{12}$ manifestosu.

İtalyan Yeni Gerçekçiliği 1950’lerde, Fransız Yeni Dalga akımı ise 1968'lerde etkisini kaybetmiştir. Ancak bu akımlar dünyanın başka yerlerinde gerçekçi film yapımının kalıcı bir parçası haline gelmiştir. Yeni Gerçekçilik akımı, Dünya sinemasını yenilikçi set tasarımı yaklaşımıyla etkilemiştir. Yeni Dalga sayesinde ise, mekânda çekim, profesyonel olmayan oyunculara ve doğal ışığa duyulan ilgi artmıştır (Nochimson, 2013: 64). Sinemada akımlar, tüm türleri etkilemektedir. Nitekim belgesel sinemada da dönemler içinde farklı arayışlar gözlemlenebilir.

5 İngiliz Belgesel Okulu'nun kurucusu John Grierson'dır. Onun ortaya koyduğu ilkeler, yetiştirdiği öğrenciler ve kendinden daha sonra gelen belgeselcileri derinden etkilemiştir (Rotha, 2000: 24).

6 Asıl ismi "Denis Arkadievch Kaufmann"dır.

7 Vertov'un deneysel çalışmaları Sovyet belgesel sineması için bir açılım olarak ele alınmaktadır. Vertov, "Kinoki" (Sinema-Göz Grubu) ismiyle bir grup kurmuştur. Grup sık sık filmlerdeki tiyatro etkisini protesto eden bildiriler yayınlamıştır. Vertov 1922'de "Kino Pravda" (Sinema-gerçek) adı altında haftalık haber görüntüleri yayınlamaya başlamıştır. Vertov, burjuva sinemasına olan eleştirisini göstermek için; Moskova'nın barlarını, kafelerini, bazı büyük mağazalarını, pazar yerlerini çoğu kez izinsiz ve gizli kamerayla filme almıştır (Akbulut, 2012: 28-29)

8 1960'larda Fransa'da Sinema-gerçek (Cinema-verite) akımı hâkim olmuştur. Sinema-gerçek, Dolaysızsinemadan, kameranın varlığının bir farklıık yarattığını ve bundan faydalanmayı kabul etme konusunda ayrılmıştır. Antropolog Jean Rouch ile toplumbilimci Edgar Morin'in yaptığı Bir Yaz Kroniği (1960) Sinemagerçeğin ilk örneklerindendir. Onaran'a göre; "Rouch, Vertov'un belgesel kuramını sentezleyerek, Sinemagerçek akımı yeniden yorumlamıştır” (1999: 117).

9 Dolaysız-sinemada, sinemacılar neredeyse gazeteciler kadar özgür birer muhabir haline gelmiştir. Akımın ilk öncülerinden olan Robert Drew, Maysles Kardeşler, Ricky Leacock ve Don Pennebaker hafif kameraları ve senkronize teypler kullanarak filmler çekmeye başlamıştır. Onların kullandıkları yöntemler, belgesel sinemada radikal bir yönelime gidişe neden olmuştur. Maysles Kardeşler, kurmaca olmayan filmler serisi içinde bu tekniği kurumsal alana adapte etmiştir. Böylece, Dolaysız-sinema akımı Amerika'da yönetmenin aksiyona karışmasına olanak tanımıştır (Monaco, 2010: 302-303)

10 İtalyan Yeni Gerçekçiliği, çağdaş sinemada gerçekçiliğin çıkış noktası olarak kabul edilir. Nitekim sinemada daha önceden de gerçekçi akımlar ortaya çıkmıştır. Bkz. Biryıldız, Esra. (2000). Sinemada Akımlar. İstanbul: Beta.

11 Yeni Dalga yönetmenleri, gerçek yaşamın akışına olabildiğince müdahale etmeyecek bir sinema dili arayışına girmiştir. Yeni Dalga yönetmenleri, Yeni Gerçekçilere (özellikle Rosselini'ye) özenmiştir ve stüdyo film yapımının tersine, kendilerine mizansen olarak Paris'teki ve civarındaki gerçek mekânları tercih etmiştir. Dış mekânda çekim yapmak kural haline gelmiştir (Bordwell ve Thompson, 2012: 476).

12 Dogma 95 manifestosunda, kamera aktüel olarak kullanılmış, film renkli ve $35 \mathrm{~mm}$ formatında çekilmiş (bu kural daha sonra filmin dijital ile çekilebileceği ama $35 \mathrm{~mm}$ gösterilmesi gerektiği şeklinde düzeltilmiştir), mizansenin önemli unsurları yasaklanmış, gerçek mekânda çekim yapma ve mekândaki eşyalarla yetinme şartı getirilmiştir. Danimarkalı yönetmenler, Dogma kurallarıyla saf sinemayı elde etmeyi amaçlamıştır (Topçu, 2013: 193). 
Siegfried Kracauer, 1960'da yayınlanan "Film Kuramı" kitabı (Theory of Film) ile gerçekçi sinema kuramına yeni bir bakış açısı getirir. Siegfried Kracauer kitabında, sinemasal gerçekliği, Robert J. Flaherty ve Yeni Gerçekçilik akımının bazı filmlerden örnekler. Siegfried Kracauer, sinemanın araçlarını iki gruba ayırır: Temel özellikler ve teknik özellikler. Filmin temel özellikleri tamamen fotografiktir, sinemanın görünebilir dünyayı ve onun hareketini kaydedebilme yeterliliği ile ilgilidir. Siegfried Kracauer için sinema, fotoğrafik temellidir, ardından teknik temel gelir (Andrew, 2010: 195). Siegfried Kracauer'e göre; "[...] yönetmenin hammaddesi fizik gerçekliktir ve aslında sanat ürünleri içinden çıktıkları hammaddeyi tüketirken, filmler kameranın doğal bir sonucu olarak bu hammaddeyi, yani fizik gerçekliği sergilemek zorunda olduğu için diğer sanatlardan ayrılır" (Aktaran Özarslan, 2013: 204). Siegfried Kracauer, sinemasal gerçekliği yakalamak için, oyuncu olmayan, öykünün gerektirdiği ortamda yaşayan gerçek kişilerin kaydedilmesini savunur. Ona göre filmde insanlar dışında başka bir sürü görünür olguda olduğu için, oyuncu anlatının merkezi değildir. Oyuncu olmayan kişilerin, gerçekliği daha kolay sağlayabileceğini belirtir (Özarslan, 2013: 212).

Fotoğrafın ve dolayısıyla sinemanın işlevi, tarihçinin işlevine benzetilebilir. Sinemanın görevi, göze çarpan her şeyi, ayrım gözetmeksizin yeniden üretmek değil, şeyin doğasında olanı keșfedip ortaya koymak, ayıklayıp vurgulamaktır. Sinema bir sanattır ama bir farkla, geleneksel sanatların (resim, heykel vb) tersine hammaddesini tümüyle tüketme amacı taşır (Kracauer, 2014: 71). Nitekim Siegfried Kracauer, yönetmenin gerçekliğe biçim vermesini eleştirir. Yönetmenin asıl görevi, fiziksel gerçekliği yansıtmak olmalıdır. Sinemada fiziksel gerçekliği en iyi yansıtan türün belgesel olduğu iddia edilebilir. Belgeselde, yönetmen ham görüntüler içinden seçimler yapar ve kurgu yoluyla gerçekliği inşa eder.

Siegfried Kracauer'in aksine, Andre Bazin, sinemasal gerçekçilik ile ne kastetmek istediğine açıklık getirir. Andre Bazin'in, gerçekçiliğe ilişkin kuramsal yaklaşımları, İtalyan Yeni Gerçekçiliği akımına dayanır. Andre Bazin'e göre; İtalyan Yeni gerçekçiliği, her çeşit dişavurumculuktan uzak biçimiyle, sinema gerçekçiliğinin en saf halini sunar (1966: 66). Belgeselin gerçekçilik savı, fotoğrafik temsil ile ilişkili olabilir. Örneğin, filmlerde kamera, bir teleskop veya mikroskop işlevi görebilir. Kamera lensiyle, dramatik etki oluşturmanın sınırı yoktur (Bazin, 2011: 107).

Andre Bazin'e göre, "fotoğrafın estetik kalitesi gerçekliğin çıplak gücünü göstermektedir. Bunlar dünyanın nesnel görünümleridir. Bir kaldırımın nemliliği, bir çocuğun yüzündeki ifade hep dış dünyadan olduğu gibi alınmış oluşumlardır. Bu güç sayesinde fotoğraf doğanın taklit edilmesinden daha fazla özellikleri içinde barındırabilir" (Aktaran Ünal, 2010: 8). Andre Bazin'in yaklaşımları, uzamsal gerçeklik oluşturmakla ilişkilidir. Andre Bazin, gerçekçiliğe ilişkin yaklaşımlarını, Robert J. Flaherty’nin Kuzeyli Nanook belgeselinden örnekler.

"Nanook filminin ünlü fok balığını avlama sahnesinde aynı çekim içinde avcı, delik ve fok balığı bir arada kullanılmamıştır. Bu durum olay anındaki uzamsal boyutun gerçeklikle, hayal ürünü olma arasındaki ayırım sorununu beraberinde getirmektedir. Flaherty, kural olarak bunu bilmesine karşın bu tür bir çekimi tercih etmiştir. Buz deliğinin kenarındaki Nanook'un fok balığını avlama görüntüsü, tüm sinema tarihi içinde ayrı bir yeri olan bir çekim şaheseridir” (Bazin, 2011: 61). 
Nitekim Kuzeyli Nanook'un öyküsünde, Robert J. Flaherty, hem zorunlu hem de kabul edilemeyen bir çelişkiyi de sunar: Gerçekçilik savı ve estetik kaygılar. Aslında ham gerçeklik, sanatın amacı değildir ve gerçekçi bir sanat, aynı zamanda estetik de olabilir. Belgesel de kurmaca gibi, bir sanattır. Ve sanatın toplumda önemli bir işlevi vardır. Nitekim belgeselde sunulan gerçekçilik, gündelik gerçeklikten farklı olabilir. Belgeselde temsil edilen gerçekçilik, sanat formunun içinde ve süreç ile birlikte oluşur. Bir başka deyişle, belgeselin konusu gerçek olabilir; ama gerçekçilik temsil ile ilişkilidir. $\mathrm{Bu}$ bağlamda, belgeselde temsil edilen gerçekçilik kaygan bir zemin üzerinde midir? Bu sorunun cevabı için belgesel ile gerçekçilik ilişkisi sorgulanmalı ve belgeselin tanımı belirlenmeye çalışılmalıdır.

\section{Belgesel ve Türler}

Belgesel $^{13}$ tanımını, ilk olarak Robert J. Flaherty'nin Moana ${ }^{14}$ (1925) filmi üzerine yazmış olduğu bir incelemede, John Grierson ${ }^{15}$ kullanır. John Grierson belgeseli; "gerçeğin yaratıcı bir biçimde işlenmesi ya da gerçeğin yaratıcı bir biçimde yorumlanması" olarak ifade etmektedir ${ }^{16}$ (Adalı, 1986: 13). Belgesel sinema eleştirmeni Paul Rotha, belgesel olarak adlandırılan film yönteminin, sinema tarihi içinde herhangi bir zamanda apayrı özellikleri olan bir tür olmadığını manifesto şeklinde, belirli bir üretim biçimi olarak çıkmadığını belirtir (Rotha, 2000: 49). Paul Rotha'ya göre belgesel, "öğretici filmlerin basit tanımlayıcı terimlerinin ötesinde, hayal gücüne daha fazla yer veren, daha vurgulayıcı, anlam yaratma konusunda daha derin değerler taşıyan, biçem yaratma daha yetkin, gözlem alanında daha geniş bir bakış açısına sahiptir" (Aktaran Susar, 2004: 11).

Belgeselciler gözlemlediklerini yeniden düzenleyebilirler, fakat öykü yazarlarının yaptıkları gibi tamamen hayal ürünlerine dayandıramazlar. Nitekim belgesel; kurmaca, roman ve diğer film yöntemleriyle kıyaslandığında daha fonksiyonel, çeşitli ve esnektir (McLane, 2012: 3-4). Günümüzde belgesel tanımı konusunda tartışmalar, devam etmektedir. Tartışmaların odak noktası, belgeselin yapım yöntemleri üzerine olmuştur. Belgesel bir biçim mi? Anlam mı? Tür mü? Yoksa gerçekliğin filme alınması mı? Olduğu konusunda sınırlar çizilememiştir.

Bir filmin belgesel tanımına girmesi için üç temel yaklaşım bulunmaktadır: Gerçeği açıklama, gerçeği yeniden inşa etme ve gerçeği soruşturma. Gerçeği açıklama, yeryüzünü en yalın biçimiyle olduğu gibi göstermeyi amaçlayan bir gelenektir. Gerçeği yeniden inşa etme, gerçekle doğrudan kurulan bağlantıyı bir yana bırakıp gerçek yaşamın inandırıcı bir benzerini yansıtmayı amaçlar. Bu daha çok kurmacada rastlanan bir gerçekçilik anlayışıdır. Gerçeği soruşturma ise, ulaşılmak istenen, görünen gerçeğin altında yatanın yani gerçeğin özünün araştırılmasıdır (Adalı, 1986: 15-16).

13 Sinema ve Televizyon Terimleri Sözlüğü'nde belgesel; belge niteliği taşıyan film veya televizyon izlencesi olarak tanımlanmaktadır (Özön, 1981: 359)

14 Filmin künyesi için bkz. http://www.imdb.com/title/tt0017162/?ref_=fn_al_tt_2

15 İngiltere'de 1929'da John Grierson'un başlattığı belgesel sinema akımı, özellikle Arthur Rank adında zengin bir sanayicinin sağladığı finansman desteğiyle güçlenmiştir. John Grierson okulunun etkileri; Basil Wright, Harry Watt, Paul Rotta, Arthur Elton, Edgar Anstey, Stuart Legg, John Taylor ve Robert J. Flaherty, gibi pek çok belgeselci de görebilir (Betton, 1993: 62)

16 John Grierson, bu tanımlamadan sonra şu sözleri de ekler; "Belgesel hantal bir tanım ama bırakalım iş görmeye devam etsin" (Beattie, 2008: 1'den Aktaran Saunders, 2010: 24). Nitekim John Grierson, belgesel ifadesinin yetersiz kalacağını düşünmüş olabilir. Günümüzde belgesel tanımı yaygındır; ama kurmaca olmayan, kurgusal olmayan gibi ifadeler de kullanılmaktadır. 
Paul Rotha kitabında ${ }^{17}$ belgeselleri; gerçekçi gelenek, haber-gerçek gelenek, doğalcı (romantik) gelenek ve propaganda geleneği olarak dört kategoriye ayırır. Her filmin belgesel nitelikler taşıdığını iddia eden Bill Nichols ise belgeseli beş kategoride inceler: Açıklayıcı belgesel, gözlemsel belgesel, interaktif belgesel, refleksif belgesel ve edimsel belgesel. Açıklayıcı belgeselde, dış-ses anlatım ağırlıktadır. John Grierson'ın Drifters ${ }^{18}$ (1929) ve Alberto Cavalcanti'nin Coalface $^{19}$ (1935) belgeselleri bu türün içindedir (Buckland, 2010: 163). Gözlemsel belgesel, belgeselcinin olaylara müdahil olmaması ile karakterize olur. Bu belgesellerde dış-ses ve röportaj kullanılmaz. Belgesel yönetmeni tamamen görünmez olmaya çalışır. Başka bir deyişle, nötr ve yargıdan uzaktır (Buckland, 2010: 169). Interaktif belgesel, gözlemsel belgeselin tam tersine; röportajlara dayanır ${ }^{20}$. Yönetmen, belgeselin bir arada tutulmasına hizmet eden ana kişidir: Michael Moore'un belgeselleri bu türe örnek verilebilir. Örneğin, Roger and $\mathrm{Me}^{21}$ (1989) ve Fahrenheit 9 /1122(2004) (Buckland, 2010: 171). Refleksif belgeselde, izleyicilere film yapım aşamalarının nasıl oluştuğu gösterilmeye çalışılır. Dziga Vertov'un Man with a Movie Camera ${ }^{23}$ (1929) belgeseli, refleksif belgesellerin en ünlü örneklerinden biridir. Dziga Vertov olayları kaydeden kamerayı, kurgu masasındaki çekimleri ve kurgucuyu, perdeye yansıtılan filmi ve sinemada filmi izleyen insanları gösterir (Buckland, 2010: 177- 178). Edimsel belgesel, kurmaca yapılara benzer. $\mathrm{Bu}$ belgesellerde, stilize edilmiş çekimler, canlandırmalar veya müzikler yer alabilir (Buckland, 2010: 179).

Belgesel tanımı, perdede yansıyan görüntünün seyircide uyandırdığı izlenimle ilgilidir. Bu nedenle belgeselleri türlere, kategorilere ayırmak çoğu zaman zor olabilir. Çünkü bazı belgeseller bir türe ait gibi görünürken, diğer türün de özelliklerini de içerebilir. Ayrıca belgesel olmayan bazı filmler de, kurmaca olmayan anlatım biçimlerine sahip olabilir: Docu-drama ${ }^{24}$ (Documentary Drama) ve Sahte-Belgese ${ }^{25}$ (Mockumentary) gibi. Belgesel ve kurmacanın kaynaşmasında tüm temsil sorunları açıklıkla sorgulanmalıdır. Belgeselde melezlik sorunu sanatsal veya kapitalist kaygılar nedeniyle ortaya çıkmış olabilir. Nitekim canlandırma belgesellerde bu kaygılar, animasyonlarla giderilmektedir.

17 Bkz. Rotha, Paul. (2000). Belgesel Sinema. (Çeviren: İbrahim Şener). İstanbul: İzdüşüm 18 Filmin künyesi için bkz. http://www.imdb.com/title/tt0019838/?ref_=fn_al_tt_10

19 Filmin künyesi için bkz. http://www.imdb.com/title/tt0182912/?ref_=fn_al_tt_1

20 Belgesel uzmanı Bill Nichols, geleneksel belgesellerde "röportaj" yönteminin en yaygın yöntemlerden biri olduğunu iddia etmektedir. Bkz. Nichols, Bill. (2001). Introduction to Documentary. Bloomington \& Indianapolis: Indiana University. Belgesel kanallarında, yayınlanan belgesellerde röportaja dayalı pek çok örnek bulunmaktadır. Bu yönteminin sıklıkla kullanımı "talking heads" ifadesiyle eleştirilmektedir.

21 Filmin künyesi için bkz. http://www.imdb.com/title/tt0098213/?ref_=fn_al_tt_1

22 Filmin künyesi için bkz. http://www.imdb.com/title/tt0361596/?ref_=fn_al_tt_1

23 Filmin künyesi için bkz. http://www.imdb.com/title/tt0019760/?ref_=fn_al_tt_1

24 Yarı-belgesel, gerçek-kurmaca, gerçeğe dayanan drama veya docu-drama olarak da isimlendirilir. Belgeselden farkı, gerçek kişiler yerine oyuncuların kullanılması ve gerçekte yaşanmış olayların öyküleştirilerek sunulmasıdır. Günümüzde, docu-drama anlatıların kurmacaya yaklaştığı ve giderek belgeselden uzaklaştığı düşünülmektedir (Rosenthal, 2002: 277).

25 "Sahte-belgeselin 'belgesel' kısmı biçimidir, sahte-kısmı ise, kurmacanın kendisidir. Belgeselin malzemesi gerçeklerdir. Sahte-belgeselin malzemesi ise gerçek gibi gösterilen sahte belgelerdir. Tarihsel bir olaydan bahsediliyorsa, sahte fotoğraflar, video kayıtları, olay kişileriyle yapılmış eski ya da yeni (gibi görülen) röportajlardır" (Demoğlu, 2010: 36). Sahte-belgesellerin başında ve sonunda filmin sahte olduğuyla ilgili bir açıklama yoktur. İzleyici, izlediği filmin gerçek olmadığını anlamaz. Sahte-belgeseller biçimsel olarak belgesel gibidir. Ancak kurmaca gibi öykü yapıları vardır ve gerçek değildirler. Bkz. Demoğlu, Elif. (2014). Düş ile Gerçek Arasında: Sahte-Belgesel. İstanbul: Doğu. 


\section{Canlandırma ve Canlandırma Belgesel Türü}

Canlandırma, çizimlerin ya da nesnelerin, hareketli ve canlı oldukları yanılsamasını uyandıracak biçimde düzenlenmesi işlemidir (Şenler, 2005: 100). Canlandırma yöntemi, içinde birden fazla tür barındırır: Canlı resim, kukla filmi, gölge filmi, alıcısız film ve bilgisayar canlandırması gibi. Canlı resim, çizgi-film diye de tanımlanır. Canlı resim hazırlanırken, senaryosu baştan sona resimlenir. Sonra bu taslağa göre ses kuşağı eşlenir. Hareket parçalara bölünür, bu parçaların her biri elle tek tek boyanır ve filme aktarılır. Kukla filmi, oyuncular yerine kuklaların kullanıldığı filmdir. Gölge filmi, canlı resim ile kukla filmin birleşiminden oluşur. Alıcısız film, çizime dayanır. Canlandırma sanatçısı resimleri doğrudan film üzerine çizer. Bilgisayar canlandırması, 1980'lerin başlarında uygulamaya geçmiştir (Özön; 2010: 258-262). Günümüzde, bilgisayar tabanlı $\left(\mathrm{CG}^{26}\right)$ canlandırmalar yaygınlaşmaktadır. Bu canlandırmalarda "Zenginleştirilmiş Gerçeklik" (Augmented Reality) olarak tanımlanan, daha ileri gerçeklikler de yaratılabilir (Song, 2009: 3-10).

Canlandırma türü, genellikle çocuklara yönelik çizgi-filmler ile kıyaslanır. Hâlbuki canlandırma yöntemi, deneysel ve belgesel sinemanın da önde gelen araçlarındandır (Bordwell ve Thompson, 2012: 382). Örneğin, Winsor McCay'ın The Sinking Of The Lusitania ${ }^{27}$ (1915) filmi, kurmaca olmayan malzemelerle oluşturulmuş ilk canlandırmadır. Filmde, bir Alman denizaltısının, bir İngiliz yolcu gemisini batırması canlandırılmaktadır. Nitekim bu canlandırma, gerçek bir olaya ${ }^{28}$ da dayanmaktadır. Filmde, topluluk halinde koşan insanlar ve bir annenin çocuğunu kurtarma çabası öykülenir. Bir diğer gerçekçi canlandırma uygulaması, Paul Vester'ın Abductees ${ }^{29}$ (1995) filminde gözlemlenebilir. Filmin öyküsünde, uzaylılar tarafından kaçırıldığını iddia eden kişilerin ses kayıtları, canlandırmalar eşlinde sunulmaktadır (Sheila, 2005:7).

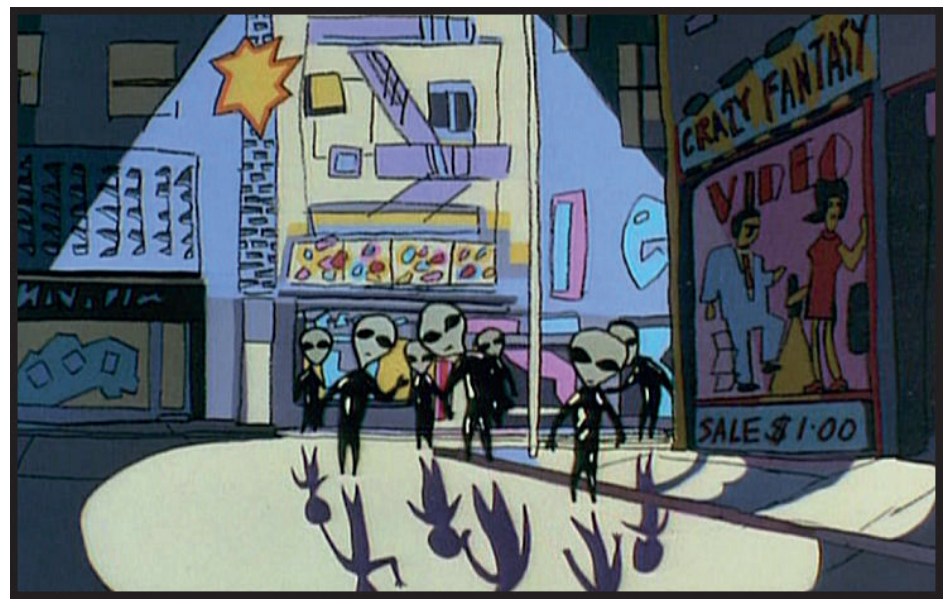

Görsel 1. Abductees (1995)

26 Computer Generated Image. Bilgisayarda Yaratılmış görüntü.

27 Filmin künyesi için bkz. http://www.imdb.com/title/tt0009620/?ref_=fn_al_tt_1

28 Amerika Birleşik Devletleri'nin Birinci Dünya Savaşına girmesine neden olmuştur.

29 Filmin künyesi için bkz. http://www.imdb.com/title/tt0178214/?ref_=fn_al_tt_1 
Günümüzde canlandırma yöntemi, pek çok kurmaca, belgesel ve docu-drama anlatı da kullanılmaktadır. Örneğin, Jen Sacht'ın The Velvet Tigress ${ }^{30}$ (2001) filminde Winnie Ruth Judd'ın 1930'daki cinayet duruşması canlandırılır. Filmde, canlandırmaya dayalı gazete görselleri ve canlandırma karakterler, dış-ses anlatımla sunulur. Crulic: The Path to Beyond ${ }^{31}$ (2011) filminde de, Polonya'da bir hapishanede açlık grevi sırasında ölen Claudio Crulic isimli kişinin gerçek yaşam öyküsü32 anlatılır. Filmde Romanyalı aktör Vlad Ivanov, dış-ses anlatım yöntemiyle Crulic'in öyküsünü seslendirir. Film, stop-motion ${ }^{33}$ ve cut-out ${ }^{34}$ animasyon teknikleriyle oluşturulmuştur.

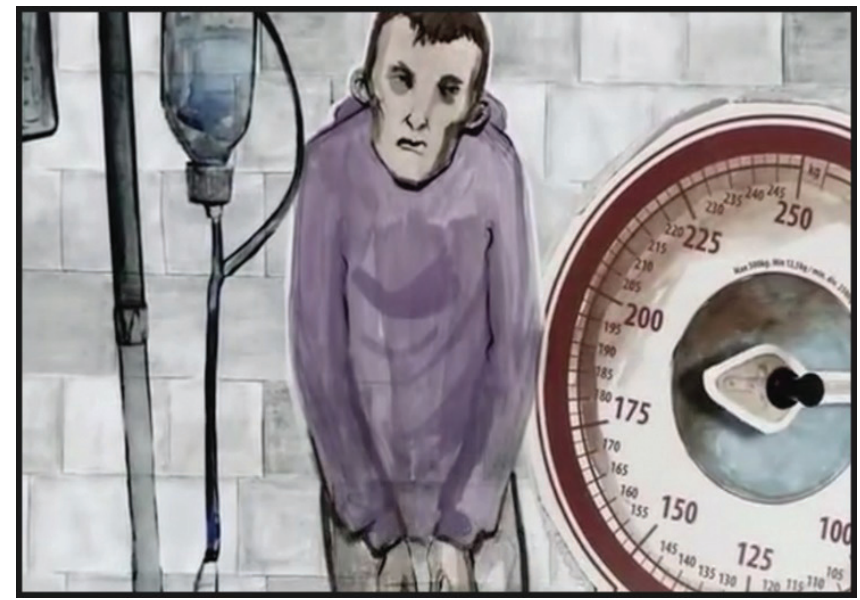

Görsel 2. Crulic: The Path to Beyond (2011)

Kurmaca ile belgesel arasında gezinen canlandırma filmlerin tarihi, geleneksel belgeseller kadar eskidir. Bu bağlamda, şu sorular sorulabilir; canlandırma belgesel (animated documentary) melez bir tür müdür? Yoksa bu filmler, belgeselde canlandırma (documentary animation) yöntemlerinin kullanıldığı filmler midir?

Canlandırmaya dayalı belgesel, İngilizce'de "Animated Documentary" olarak ifade edilmektedir ${ }^{35}$. Bu tür filmler için; "canlandırılmış belgesel"36, "animasyonlu belgesel", "belgesel canlandırma" veya "canlandırma belgesel" gibi ifadeler de kullanılmaktadır. Canlandırma belgesellerde, gerçek-çekimler ${ }^{37}$ (live-action) yerine, iki boyutlu veya

30 Filmin künyesi için bkz. http://www.imdb.com/title/tt0297451/?ref_=fn_al_tt_1

31 Filmin künyesi için bkz. http://www.imdb.com/title/tt1996223/

322007 yılında, Polonyalı bir Yargıç'ın cüzdanı çalınır. Claudio Crulic, cüzdanı çalma suçundan tutuklanır.

33 Bu teknikte, fotoğraf makinası nesnelere karşı ayarlanır ve tek kare fotoğraf pozlanır. Ardından nesneler biraz hareket ettirilir. Filme alınan tek kare fotoğraflar sıralanarak kurgulanır. 1907'de J. Stuart Blackstone, stopmotion tekniğini kullanarak "Humorous Phases of Funny Faces" adlı animasyon filmini yapmıştır. Bu tarihten itibaren, bu teknikle, birkaç tane daha animasyon çekilmiştir. Ancak 1914 yılı animasyon tarihinde bir dönüm noktasıdır (Şenler, 2005: 102).

34 Kesme-çıkarmaya dayalı, bir animasyon tekniğidir.

35 Bkz. (Roe, 2013: 5)

36 Araştırmada "canlandırma belgesel" ifadesi kullanılmıştır.

37 Oxford İngilizce sözlüğünde; gerçek oyuncularla çekilmiş gerçek-çekim olarak geçmektedir. Çalışmada, "gerçek-çekim" ifadesi kullanılmıştır. 
üç boyutlu animasyonlar kullanılmaktadır. Canlandırma belgesellerin pek çoğunda görüntüler; çekim sonrasında inşa edilir: Doğal sesler ve röportaj kayıtlarına uygun olarak. Canlandırma belgesellerde gerçek ses kayıtları kullanılır ve yaşanmış olaylar yeniden canlandırılır.

Annabelle Honess Roe (2013) kitabında ${ }^{38}$, canlandırma belgesel türünü, sahtebelgesellerden ve docu-dramalardan ayırmaktadır. Ona göre; canlandırma belgesel, belgesel için yeni bir görsel temsil strateji olarak görülmelidir (Roe, 2013: 33). Nitekim 1990'lardan beri, belgeselde canlandırma kullanımı, teknolojik gelişmelere paralel olarak yaygınlaşmaktadır. Almanya'da DoK-Leipzig ${ }^{39}$ ve Hollanda'da Uluslararası Belgesel Festivalinde, her yıl pek çok canlandırma belgesel gösterilmektedir.

Geleneksel belgesellerde, belgeselciler kamera kayıtlarının eksikliğini telafi etmek, olayları görselleştirmek veya vurgulamak için canlandırmalar kullanabilir. Günümüzde pek çok geleneksel belgeselde, canlandırma yöntemi yer almaktadır. Örneğin, Michael Moore'un Bowling for Columbine ${ }^{40}$ (2002), Judith Hefland ve Daniel B. Gold'ın Blue Vinyl ${ }^{41}$ (2002), Gwen Haworth'In She's a Boy I Knew ${ }^{42}$ (2007) belgesellerinde ironik canlandırmalar yer almaktadır. Bu filmlerde, canlandırmalar, mizahi bir anlatımla gerçekliği sunarlar.

Annabelle Honess Roe, kitabında canlandırma belgeselleri anlatım yöntemlerine göre kendi içinde sınıflandırır: Mimetik ikame, mimetik olmayan ikame ve çağrışım yapma (Roe, 2014: 228). Annabelle Honess Roe'e göre; "Canlandırma belgeseller, geleneksel belgesellerin gerçeklik savını; mimetik ve mimetik olmayan temsiller yoluyla gösterirler" (2013: 26). Annabelle Honess Roe, mimetik ikameleri ${ }^{43}$ dijital gerçekliklerle ${ }^{44}$, mimetik olmayan ikameleri de canlandırma röportajlarla ifade etmektedir. Annabelle Honess Roe, bu sınıflandırmaya; öznel temsilleri ve canlandırma anıları ${ }^{45}$ da eklemektedir.

"Günümüzde canlandırma belgesellerde en çok tercih edilen yöntemlerden biri rotoshop ${ }^{46}$ tekniğidir. Bu yöntemde röportaj kayıtları temsili bir gerçeklikle sunulur. Rotoshop yönteminde, ses kayıtlarına stilize edilmiş canlandırmalar eşlik eder. Canlandırma belgesellerde bu bir boşluk veya bir aşırlık olarak görülebilir” (Roe, 2011: 27).

Canlandırma belgesellerde, gerçek-çekimlerin yokluğu bazen bir eksiklik olarak

38 Bkz. Roe, Honess, Annabelle. (2013). Animated Documentary. Basingstoke, Hampshire and New York: Palgrave Macmillan

39 Bkz. http://www.dok-leipzig.de/ ve https://www.idfa.nl/industry.aspx.

40 Filmin künyesi için bkz. http://www.imdb.com/title/tt0310793/?ref_=fn_al_tt_1

41 Filmin künyesi için bkz. http://www.imdb.com/title/tt0303307/?ref_=fn_al_tt_1

42 Filmin künyesi için bkz. http://www.imdb.com/title/tt1095496/?ref_=fn_al_tt_1

43 Annabelle Honess Roe, kitabında "mimetic substitution" olarak geçmektedir. Çalışmada mimetik ikame olarak çevrilmiştir.

44 Annabelle Honess Roe, dijital gerçeklikleri Walking with Dinosaurs ve Chicago 10 filmlerinden örneklemektedir (2013: 45).

45 Annabelle Honess Roe, canlandırma anıları, Waltz With Bassir filminden örneklemektedir (2013: 155).

46 Kamera kayıtlarının, kopyalanarak animasyon biçiminde aktarıldığı teknik. Bkz. (Roe, 2011: 26). 
görülebilir. Bu nedenle, canlandırma belgesellerin sorunlu ve tartışmaya açık gerçekliği, röportaj kayıtları ile kapatılmaktadır. Birçok canlandırma belgeselde, canlandırmalar ile gerçek-çekimler birlikte kurgulanır; ama canlandırma görüntüler daha baskındır.

\section{Amaç ve Yöntem}

Çalışmanın amacı, belgeselin gerçekçilik savı ile tasarım boyutunu karşılaştırarak, gelişen yeni belgesel arayışları irdelemektir. Bu bağlamda, örnek seçilen filmler, tür eleştirisi yöntemiyle incelenecektir. Tür sözcüğü, orijinal olarak Fransızcadır ve "Genre, Kind ve Type" kelimelerine karşılık gelir (Bordwell ve Thompson, 2012: 328). Tür kuramının kökenleri, Aristo'nun "Poetika" isimli eserine dayanır. Nitekim edebi incelemelerde tür terimi, ayrımları belirtmek için kullanılmaktadır: Epik, lirik, dramatik, kurmaca, belgesel, komedi trajedi gibi.

Tür filmleri konusundaki ilk ciddi çalışmalar, 1940'ların sonlarında Fransa'da ortaya çıkan auteur ${ }^{47}$ kuramı ile ilişkilendirilir. 1980'lerden sonra ise tür kuramında melez türler ya da türlerin dönüşümü gibi kavramlar, tartışılmaya başlanmıştır (Özarslan, 2013: 51-53). Tür eleştirinin öncelikli konulardan birisi, bir olgu olarak filmin türünün tanımlanmasıdır. Bu bağlamda, tür ile ilgili sorunların tartışılmasını sağlayacak kuramsal çerçeve çizilmelidir. Film türlerinin incelenmesinde diğer sanat dallarındakinden farklı güçlükler yaşanabilir. Film yapımcısı için bir film öncelikle bir üründür ve satılması gerekir. Tür eleştirisinin ana imgesi sanatçı-film-seyirci tarafından oluşturulan üçgendir (Özden, 2014: 216-217). Tür eleştirisi kurmaca için tasarlanmış olabilir; ama film dilinin işleyişine dair genel bir modeli tahayyül edersek, tür eleştirisi, dikkatimizi onun içindeki alt dillere de yöneltir. Tür, belirli bir grubun ya da toplumun kültüründe var olan bir kavramdır. Belgeselin, deneysel filmin ve canlandırma filmlerin de türleri vardır (Bordwell ve Thompson, 2012: 328).

Belgeselciler, filmlerde gerçekliği sunmaya çalışır. Nitekim bazı film eleştirmenine göre; gerçeklik göreceli bir kavramdır. Çünkü film kurgulandığı sürece, bir kısım gerçeklik filmin yönetmeni tarafından gizlenecektir. Bazı melez belgesel türlerde, bazı sahneler yeniden inşa edilebilir. Yeniden inşa edilen sahneler, halen gerçekliğe sahip midir? Bu bağlamda çalışmada, canlandırma belgesel türünün, belgesel ile olan bağlantısı ortaya konmaya çalışılacaktır.

Araştırmada; Waltz with Bashir ${ }^{48}$ (Ari Folman, 2008), Is the Man Who Is Tall Happy?: An Animated Conversation with Noam Chomsky ${ }^{49}$ (Michel Gondry, 2013) ve The Life and Mind of Mark DeFriest ${ }^{50}$ (Gabriel London, 2014) filmleri tür eleştirisi yöntemiyle incelenecektir. Canlandırma belgesel türünün özelliklerine ilişkin iki kavram yol gösterici olmuştur: Canlandırmanın etkisi ve belgeselin gerçekçilik savı. Çalışmada, bu kavramları detaylı bir biçimde ele almak için tür eleştirisine ek olarak, anket çalışması da yapılmıştır.

47 Yazar, yaratıcı. Bkz. Andre Bazin'in "De la Politique des Auteurs" (1957) isimli makalesi (Bazin, 2011: 211212).

48 Filmin künyesi için bkz. http://www.imdb.com/title/tt1185616/?ref_=fn_al_tt_1

49 Filmin künyesi için bkz. http://www.imdb.com/title/tt1817287/?ref_=fn_al_tt_1

50 Filmin künyesi için bkz. http://www.imdb.com/title/tt2766004/ 


\section{1. Örnek Filmlerin Konusu ve Türe Ait Özellikler}

\subsubsection{Waltz with Bashir}

Film, rüyasında yirmi altı köpekten kaçan Boaz Rein'in öyküsüyle başlar. Boaz Rein, eski bir İsrail askeridir. Boaz Rein, Ari Folman'a barda gördüğü kâbusları anlatır. Ari Folman, Sabra ve Satilla katliamının yaşandığı dönemde, İsrail ordusu adına Lübnan'da görev yapmıştır. Ancak Ari Folman, hayatının o dönemiyle ilgili pek bir şey hatırlamamaktadır. Bu ilginç durum karşısında, dünyanın dört bir yanından dostlarını ve asker arkadaşlarını bulup, savaşta yaşananlar hakkında konuşmaya karar verir. Ari Folman, bu gizemi deştikçe, hafızasında gerçek-üstü resimler uyanmaya başlar (http:// waltzwithbashir.com/film.html 12.04.2015).

Filmde, ana karakterin savaş sonrası bunalımı ve bu bunalıma bağlı yaşadığı hafıza kaybından kurtulma çabası işlenmiştir. Filmde, geçmişe ait anılar tanıklık eder. Filmin öyküsünde, Ari Folman'ın, ordudan arkadaşlarıyla, gazetecilerle ve uzmanlarla yaptığı röportajlar ${ }^{51}$; canlandırmalar eşliğinde gösterilir. Filmde röportajlar, karşılıklı konuşma şeklinde sunulur. Ancak filmde, belgesel sinemada bir ilke olan, görüntü ve ses arasındaki doğalıı izlenimi kökten yıkılmaktadır (Saunders, 2011: 195).

"Gerçek-çekimin fotoğrafik işlemlerden geçen (ya da dijital olarak elde edilen) gerçekçiliğinden uzak çizgisel animasyon tekniği sayesinde gerçekle gerçekdışı arasında gidip gelen film, belgesel sinemacııı̆ında değişmez olarak kabul edilen öğeleri bölerek, gerçekleşmiş olanla gerçekleşmemiş olan arasında bir sınır çizer" (Saunders, 2011: 178).

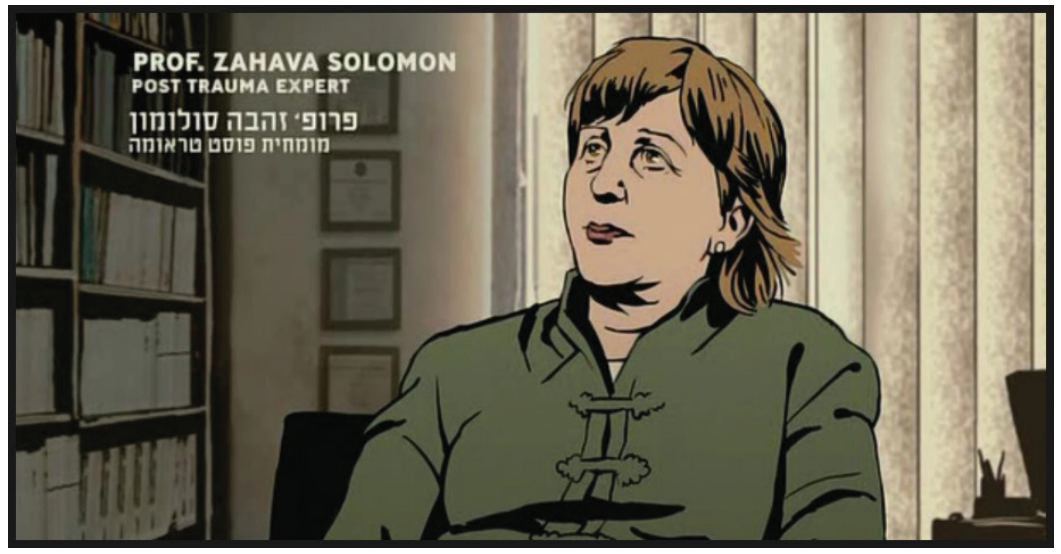

Görsel 3. Waltz with Bashir (2008)

Filmin öyküsünde Falanjistlerin ${ }^{52}$ yardım ettiği, hiç bir şeye karışmadıkları, kamplara bakan bir tepeden ordu komutanlarının her şeyi izlediği, katliamın gece de devam edebilmesi için İsrailli askerlerin aydınlatma sağladığı, kampın etrafında İsrailli askerlerin

51 Ari Folman ve arkadaşları arasında geçen diyaloglar önce kameraya alınmış, daha sonra canlandırma sanatçıları bu görüntüleri yeniden inşa etmiştir (Saunders, 2011: 178).

52 Lübnan İç Savaşı sırasında, İsrail tarafından desteklenen faşist Hristiyan milislere verilen isim. 
nöbet tuttuğu anlatılır. Filmin mesajında, "asıl suçlu falanjistler, bunu unutmayalım" denmektedir. Waltz with Bashir'de her ne kadar tarihsel hafıza masallaştırılmışsa da, olayların ve zamanın örgütlenmesi gerçekçi bir biçimde yeniden inşa edilmiştir.

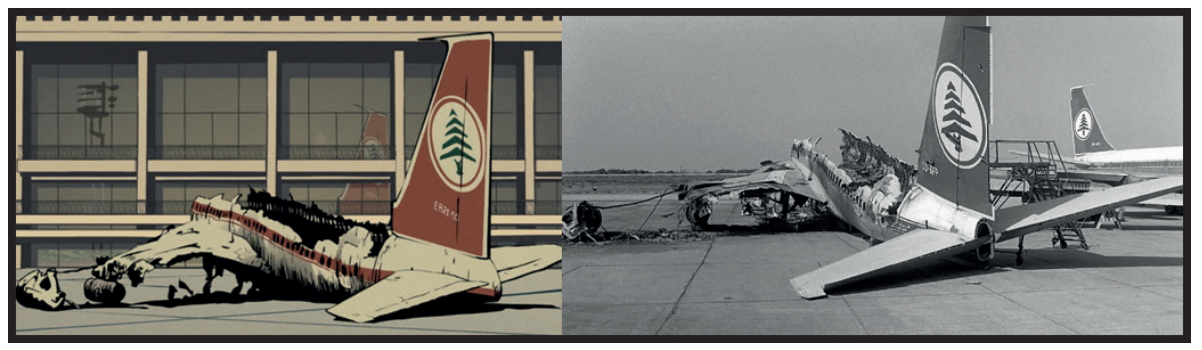

Görsel 4. Gerçeğin temsili53 Waltz with Bashir (2008)

Siegfried Kracauer, modernliğin etkilerini, fotoğraf ve sinemayla ilişkilendirmiştir. İletişim araçlarıyla hesaplaşırken, fiziksel gerçekçiliğin sunumuna ve gizlenmesine odaklanmıştır (Frisby, 2012: 194). Günümüzde fiziksel gerçeklik evreninin, değiştiği iddia edilebilir. Nitekim Siegfried Kracauer'in savunduğu fotoğraf, modern yaşamda sanal bir gerçekliğe dönüşmektedir. Modern yaşamda bireyler, gerçeğe parmak uçlarıyla bile dokunabilirler. Bu bağlamda, belgesel gerçekliğin temsilinde de arayışların olması kaçınılmazdır.

Filmin sonunda, öyküde anlatılan katliam görüntüleri, gerçek-çekimlerle birlikte sunulmaktadır. Bu durumda, canlandırma görüntülerin sunduğu gerçekliğin, yeterli retorik ağırlığa sahip olmadığı düşünülebilir. Ari Folman"54ın filmin sonunda gerçekçekimleri kullanması, bir taviz olarak görülebilir. Nitekim fotoğrafik görüntülerle gerçek anlamda etkili olabilecek bir tavizdir bu.

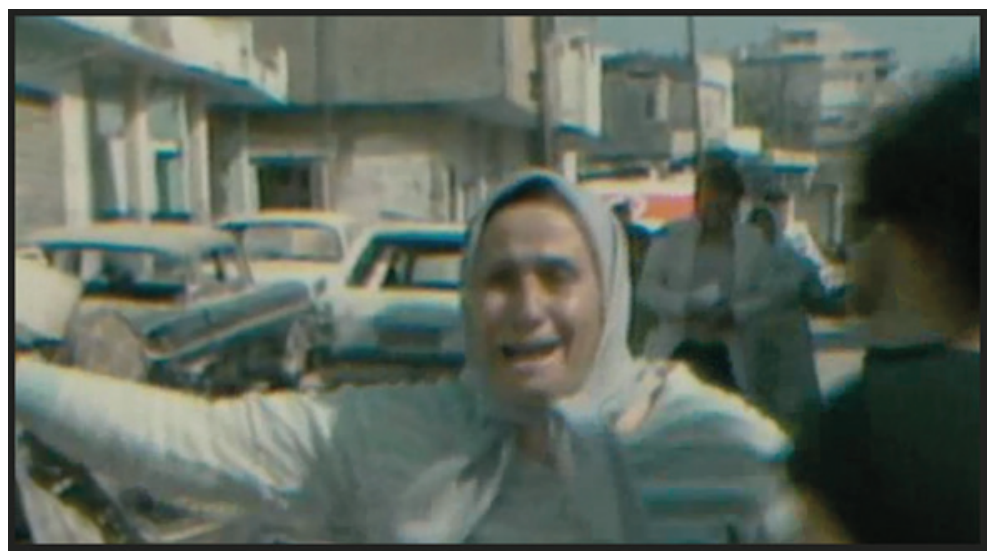

Görsel 5. Waltz with Bashir (2008)

53 Solda filmde sunulan kare, sağda Beyrut hava alanında bombalanan yolcu uçağının gerçek-fotoğrafı (Phan Robert Feary tarafından fotoğraflanmıştır).

54 Ari Folman, bir röportajda; "Insanların sinema salonunda kaliteli bir animasyon filmi izlediklerini düşünerek çıkmalarını istemiyorum" diye belirtmektedir (Aktaran Saunders, 2011: 193). 


\subsubsection{Is the Man Who Is Tall Happy?: An Animated Conversation with Noam Chomsky}

Siegfried Kracauer için gerçeklik bir inşadır. Hayatın vücut bulması için gözlemlenmesi gerekir. Röportajdaki bir dizi keyfi gözlem gereksizdir. Röportaj, toplumsal gerçekliğin yapısına dair iç görülerden kaynaklanan bir biçim kazanmadığı takdirde, soyut içeriklerden ibaret olan bir derleme olarak kalır (Aktaran Frisby, 2012: 206-207). Is the Man Who Is Tall Happy?: An Animated Conversation with Noam Chomsky'nin anlatısı, Michel Gondry'nin, Avram Noam Chomsky ile farklı zaman dilimlerinde yaptığı röportaj ${ }^{55}$ kayıtlarına dayanmaktadır. Nitekim filminaçıışsekansında yönetmen, dış-sesanlatımla, filmin gerçekliğinin manipüle edildiğini de ifade etmektedir. Filmin büyük bölümü56 (yönetmenin belirttiği üzere yüzde $98^{\prime} i$ ) canlandırmalardan oluşmaktadır. Ancak filmin bazı sahnelerinde, Noam Chomsky ve Michel Gondry'nin gerçek-çekimleri, canlandırmalarla iç içe sunulmaktadır. Bu görüntülerde, Michel Gondry, Noam Chomsky'e sorular sorarken gösterilir.

Siegfried Kracauer, lenslerle yapılan biçim bozunumlarını, optikle yapılan efektleri ve benzerlerini eleştirmektedir. Onun için sinemanın konusu fotoğraflanabilir dünyadır, fotoğrafçıya kendisini doğal olarak gösteren gerçekliktir (Andrew, 2010: 196). Michel Gondry, filmde, gerçek-çekimler yerine, canlandırma tekniklerini tercih etmesini iki nedene bağlamaktadır. Öncelikle bu yöntem, Noam Chomsky'nin düşüncelerinin gerçekliğini sunmaktadır. Yönetmenin ikinci dayanağı, canlandırmaların ${ }^{57}$ özdeşleştirmeyi canlı tutabileceği iddiasıdır. Nitekim Michel Gondry’e göre; yaklaşık iki saat süren ve röportajlardan oluşan bir film izleyicileri sıkabilir (https://thedissolve.com/ reviews/385-is-the-man-who-is-tall-happy-an-animated-conversat/ 12.08.2015).

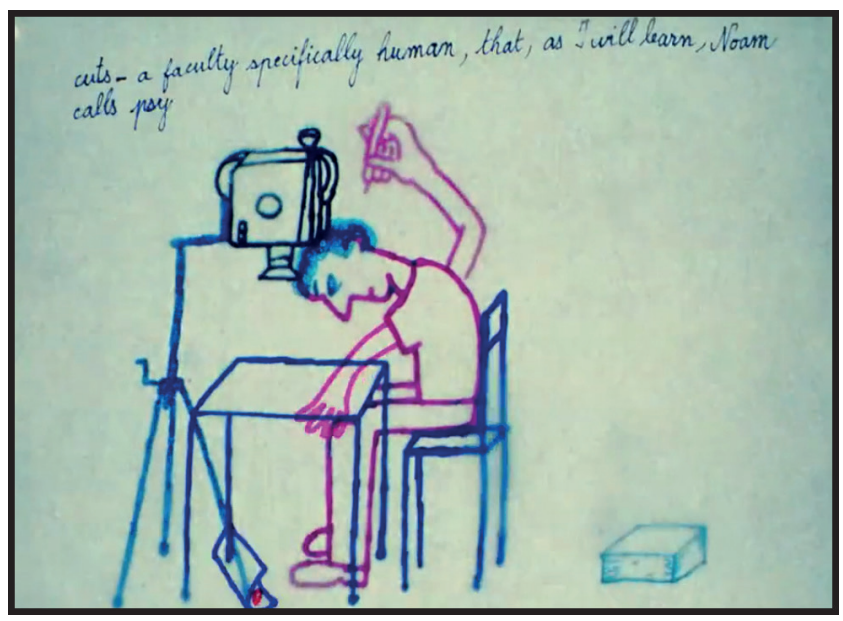

Görsel 6. Is the Man Who Is Tall Happy?: An Animated Conversation with Noam Chomsky (2013)

55 Yönetmen, filmin ilerleyen bir sekansında, Noam Chomsky ile yaptığı bir röportajın üzerinden iki sene geçtiğini dış-ses anlatımla dile getirir.

56 Filmin başında Michel Gondry, bu yöntemi daha yaratıcı bulduğu için tercih ettiğini belirtir. Michel Gondry $16 \mathrm{~mm}$ Bolex marka kamerası ile çekimler yapmasına rağmen; bu çekimler canlandırma kareler içinde sunulmaktadır.

57 Filmde Michel Gondry, özdeşleştirme kurmak ve soyut anlamları metaforlaştırmak için el çizimleri, stop motion tekniği ve xerography (elektrostatik baskı ile kopya etme yöntemi) gibi yöntemler kullanmaktadır. 


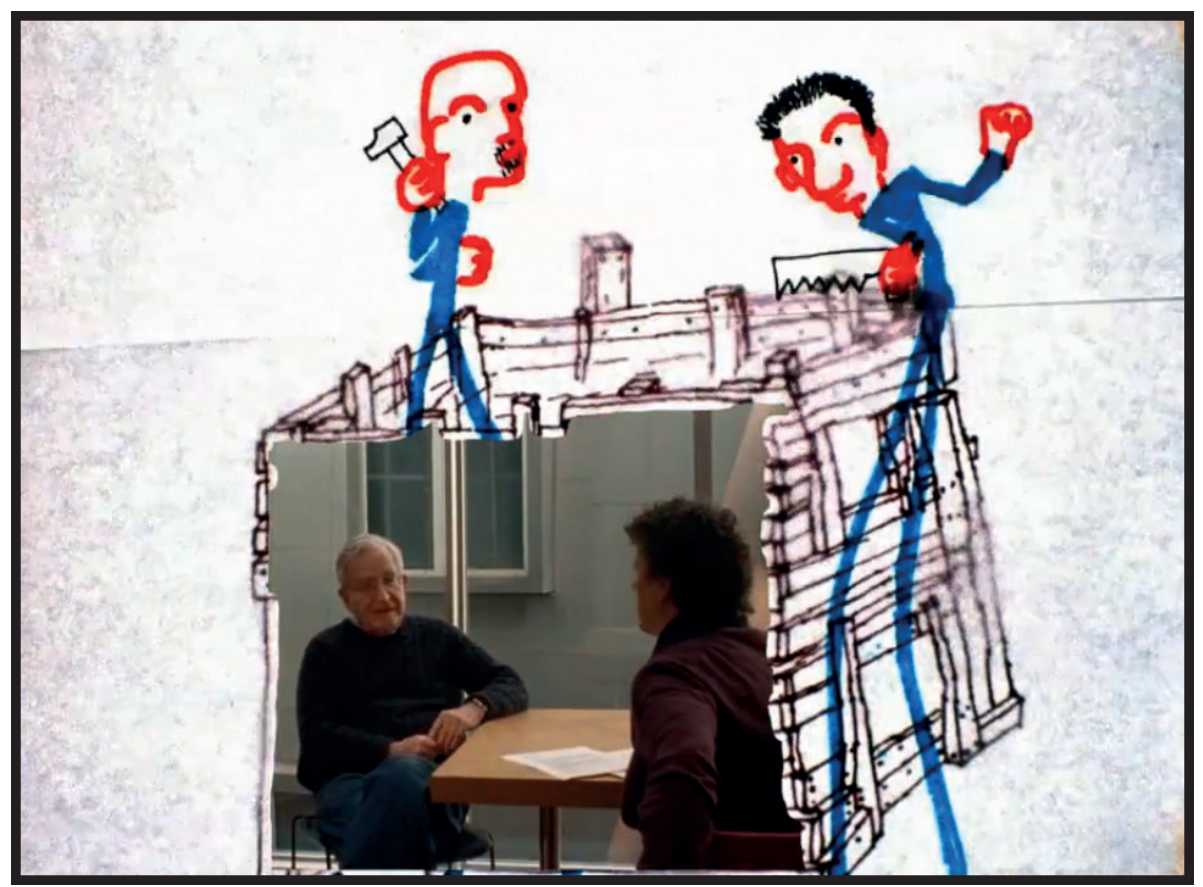

Görsel 7. Is the Man Who Is Tall Happy?: An Animated Conversation with Noam Chomsky (2013)

\subsubsection{The Life and Mind of Mark DeFriest}

Filmde, hırsızlık suçundan mahkûm edilen Mark DeFriest'in öyküsü anlatılır. Mark DeFriest, dört yıla mahkûm olmasına rağmen, firar teşebbüsleri nedeniyle cezası otuz yıla çıkar. Mahkûm olduğu sürede, Mark DeFriest, cezaevinde tecavüze uğrar ve işkence görür. Bu nedenle, cezaevinden sürekli kaçmaya çalışır ${ }^{58}$; ama eninde sonunda yakalanır. Mark DeFriest'in cezaevinde yaşadıkları yüzünden akıl sağlığı bozulur. Ancak firar teşebbüslerinde, kullandığı yöntemler ve aletler nedeniyle mahkeme, bunu göz önünde bulundurmaz. Filmde, Mark DeFriest'in avukatı, eşi ve bir doktorun mücadelesiyle; Mark DeFriest'in şartlı tahliye olma süreci anlatılmaktadır.

Siegfried Kracauer'e göre; "Rastlantısal olaylar fotoğrafların eti kemiğidir; has fotoğraflar konuları yoldan geçerken seçili vermiş gibi görünürler. Keza sinemacılar gelip geçici izlenimleri ve öngörülemeyen karşılaşmaları aktarmaya düşkündür” (2014: 78). The Life and Mind of Mark DeFriest'in pek çok sahnesi gerçek-çekimlerden, oluşmaktadır ve bazı sahnelerde bu görüntülere, arşiv görüntüleri ile fotoğraflar da eşlik etmektedir. Bu bağlamda, filmin, geleneksel belgesel türüne daha yakın olduğu iddia edilebilir. 


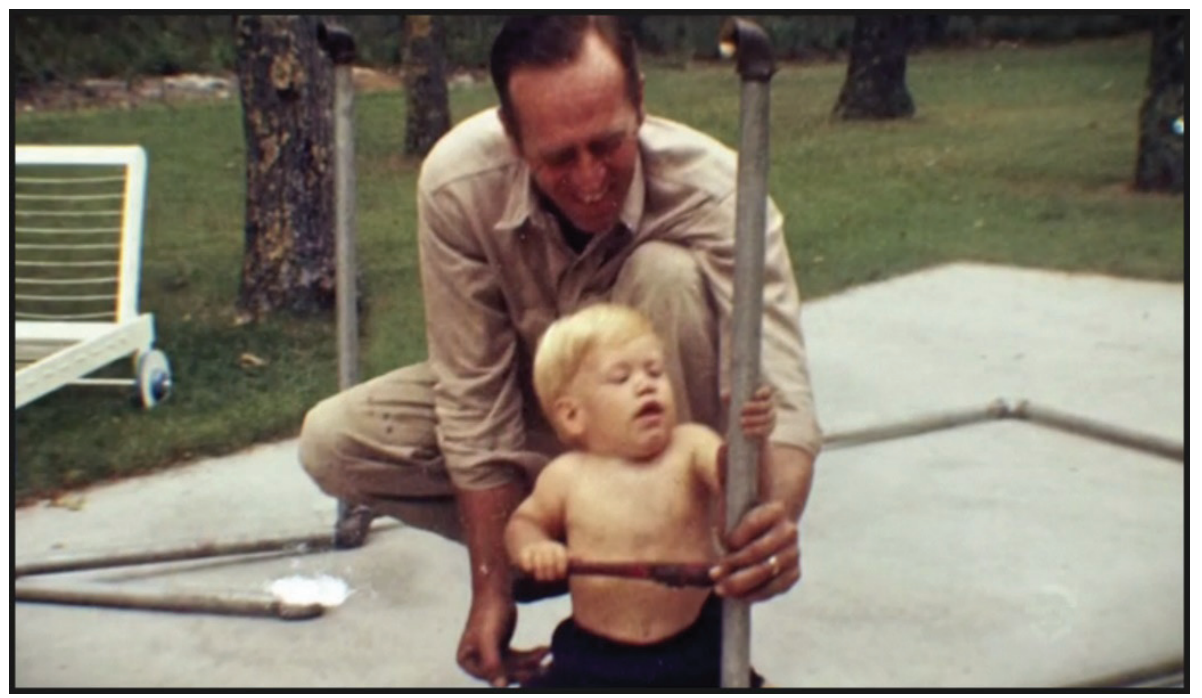

Görsel 8. The Life and Mind of Mark DeFriest (2014)

Ancak filmin bazı sahnelerinde sunulan canlandırmalar, gerçek-çekimlerle gösterilemeyecek gerçekleri de göstermektedir. Örneğin, Mark DeFriest'in tecavüze uğraması ve işkenceye uğradığı görüntüler, çizimlerle betimlenir. Nitekim bu sahnelerde, canlandırmalarla temsil edilen olayların, daha gerçekçi olduğu iddia edilebilir. Çünkü izleyicilerin filmlere dair beklentileri ve izlenimleri, filmlerin gerçeklik algısı üzerinde etkilidir ve filmdeki canlandırmalar, gözün görebildiğinden daha fazlasının da var olabileceğini göstermektedir.

"Sanatta gerçekçilik çekişmesi; estetik ile ruhbilim, dünyanın somut ve temel anlamını açığa vurmak intiyacında olan asıl gerçekçilik ile biçimlerin yanılsamasıyla yetinen göz aldatıcııı̆ın (ya da zihin aldatıcııı̆ının) yalancı gerçekçiliği arasındaki bu yanlış anlamadan, karışıklıktan ileri gelir” (Bazin, 1966: 34).

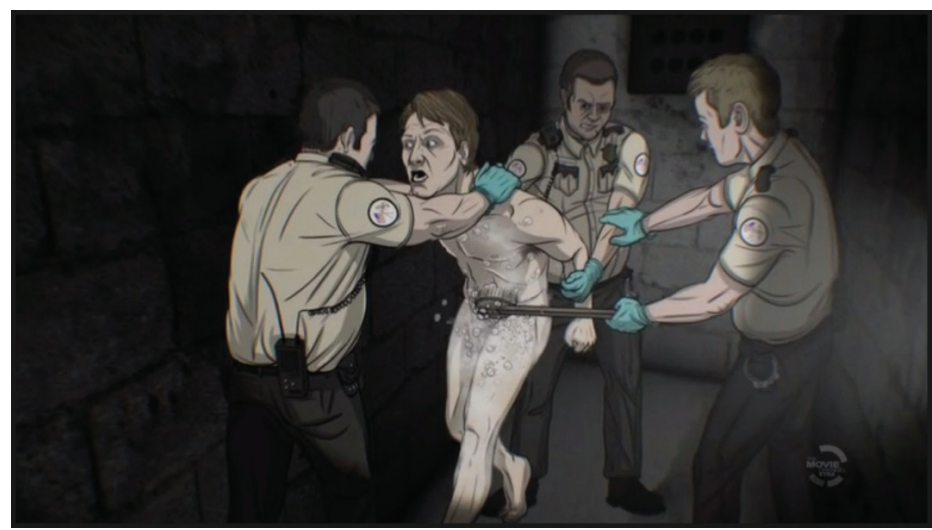

Görsel 9. The Life and Mind of Mark DeFriest (2014) 
Geleneksel belgesellerde gerçek-çekimler, somut görünümlere büründürülerek, gündelik yaşamın gerçekliğini sunabilirler. Bu yönelimde, gerçekçiliğin tasarımdan daha önemli olduğu düşüncesi olabilir. Nitekim yaşadığımız çağda gerçek, ancak modelin kopyası olabilme özelliğine sahiptir. Friedrich Nietzsche'nin dediği gibi; "Gerçek dünyayı bertaraf ettiğimize göre, geriye kalana ne dememiz gerekiyor? Görünümler dünyası mı? Kesinlikle hayır! Çünkü hakiki dünyayla birlikte görünümler dünyasını da yok ettik" (Aktaran Adanır, 2010: 163). Birçok kurmaca anlatıda, gündelik gerçekliğin yeniden inşası hedeflenebilir. Belgeselde bu iddia, uzun yıllardır sürdürülmektedir. Nitekim günümüzde dünya ve dünyaya bakış değişmiştir ve fotoğrafik görüntünün yoğunluğu, gündelik yaşamın temsillerini karşılayamayabilir. Bu bağlamda, sanatın daima tasarım olduğu düşüncesinden hareketle, filmde sunulan canlandırmalar, iyimser bir bakış açısı olarak görülebilir.

\section{5. Örnek Kütle ve Anket Formunun Yapısı}

Çalışmada, tür eleştirisi kapsamında, bazı canlandırma belgesel örnekleri incelenmiştir. Örneklemde yer alan filmlerin, seçilmesinde türe ait özellikler belirleyici olmuştur. Bu bağlamda, araştırmanın ilk örneklemini kurmaca ve belgesel yapılar içeren Waltz with Bashir filmi oluşturmaktadır. Araştırmanın ikinci örneklemi, Is the Man Who Is Tall Happy?: An Animated Conversation with Noam Chomsky filmidir. Film, röportaj kayıtlarından oluşmaktadır ve canlandırma belgesel türünün tüm özelliklerini barındırmaktadır. Üçüncü örneklem, The Life and Mind of Mark DeFriest filmidir. Filmin bazı sahneleri gerçek-çekimlere, bazı sahneleri de canlandırmalara dayanmaktadır. Her üç filmin de, ortak özellikleri ve farkları bulunmaktadır.

Araştırma kapsamında, Beykent Üniversitesi İletişim Fakültesinde öğrenim gören 77 öğrenciye üç film izlettirilmiş ve türe ilişkin anket soruları sorulmuştur. Ankette toplam 12 soru sorulmuştur. Bu sorulardan beşi, beşli likert (1=Kesinlikle katılmıyorum, $5=$ Kesinlikle katılıyorum) formunda hazırlanmıştır. Anket çalışması, betimsel türde bir çalışmadır ve analizin tek bir akademik kurumda yapılması araştırmanın temel kısıtıdır. Soruların analizinde "SPSS for Windows" programından yararlanılmıştır. Bulguların bazıları tablolar yardımıyla yorumlanmıştır. Araştırma bulguları türe ilişkin özelliklere göre yorumlanmıştır. Araştırmanın hipotezleri şu şekilde gösterilebilir:

$\mathrm{H}_{1}$ : Gerçek-çekimlerle, belgeselin gerçekçilik savı arasında anlamlı bir ilişki yoktur.

$\mathrm{H}_{2}$ : Belgeselin biçimsel özellikleri ile türe ait özellikler arasında anlamlı bir ilişki vardır.

Gerçekleştirilen literatür araştırması sonucu elde edilen bilgiler doğrultusunda oluşturulan araştırma modeli aşağıdaki şekilde görülmektedir. Modelde, türle ilgili değişkenler temel olarak ele alınmıştır.

Șekil 1: Araștırma modeli

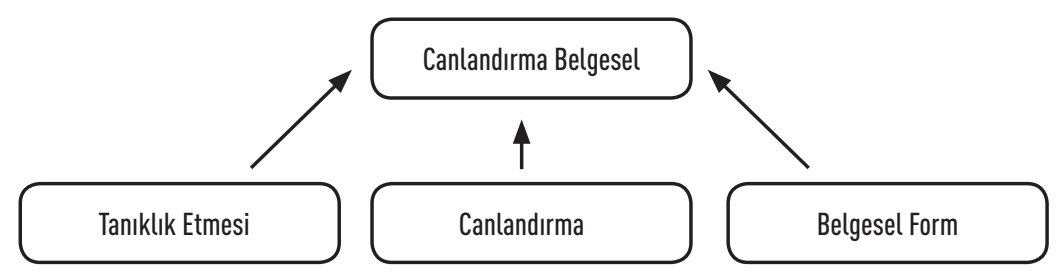




\section{Bulgular}

Anket, görsel iletişim ve yeni medya bölümlerinde eğitimi alan 77 öğrenciye yapılmıştır. Ankete katılan öğrencilerin \%59,7'si erkek, \%40,3'ü kız öğrencidir. Ankete katılan öğrencilerin cinsiyet ve yaş bilgisinin ölçümlenmesine yönelik hazırlanan sorulardan sonra, belgeselin anlatım yöntemlerinin yer aldığı bölüme gelinmiştir. Araştırma sonucu elde edilen veriler aşağıda tablolaştırılmıştır.

Tablo 1. Katılımcıların Demografik Özellikleri

\begin{tabular}{|l|l|}
\hline Cinsiyet & Erkek \%59,7, Kadın \%40,3 \\
\hline Yaș & $18-22 \% 58,4 ; 23-27 \% 29,9 ; 28-32 \% 5,2 ; 33-37 \% 3,9 ; 37-42 \% 2,6$ \\
\hline
\end{tabular}

Tablo 2. Așağıdaki Film Türlerinden Hangisi Daha Gerçekçidir?

\begin{tabular}{|l|c|c|}
\hline & Sayı & Yüzde \\
\hline Belgesel & 50 & 64,9 \\
\hline Kurmaca & 4 & 5,2 \\
\hline Otobiyografik filmler & 12 & 15,6 \\
\hline Doğa konulu filmler & 11 & 14,3 \\
\hline Toplam & 77 & 100 \\
\hline
\end{tabular}

Öğrencilerden, bazı film türlerini gerçekçilik bağlamında değerlendirmeleri istenmiştir. Öğrencilerin \%64,9'una göre, en gerçekçi film türü belgeseldir ve kurmaca \%5,2 oranla en düşük oranda yer almaktadır.

Tablo 3. Belgeseli Kurmacadan Hangi Özelliği Ayırmaktadır?

\begin{tabular}{|l|c|c|}
\hline & Sayı & Yüzde \\
\hline Bilgi vermesi & 21 & 27,2 \\
\hline Öyküsünün gerçeğe dayanması & 29 & 37,7 \\
\hline Arșiv görüntüleri içermesi & 15 & 19,5 \\
\hline Öğüt vermesi & 12 & 15,6 \\
\hline Toplam & 77 & 100 \\
\hline
\end{tabular}

Ankete katılan öğrencilere, "Belgeseli kurmacadan hangi özelliği ayırmaktadır?" sorusu sorulmuştur. Bu soruda, belgesel ve kurmacada bulunan bazı özellikler referans alınmıştır. Öğrencilerin \%37,7'si bu soruya, "Öyküsünün gerçeğe dayanması" cevabını vermiştir. Bu bağlamda, öyküleme yöntemlerinin belgesel ve kurmaca ayrımında etkili olduğu sonucuna varılabilir. Nitekim John Grierson'ın da ifade ettiği gibi belgesel yöntemi; "gerçeğin yaratıcı bir biçimde işlenmesi ya da gerçeğin yaratıcı bir biçimde yorumlanması" olarak tanımlanmaktadır. Belgeselde öyküleme biçimi ile gerçeklik iddiası arasında anlamlı bir ilişki kurulmaktadır. 
Tablo 4. Bir Belgeselin Gerçeğe Dayanması İçin Așağıdaki Özelliklerden Hangisi Mutlaka Bulunmalıdır?

\begin{tabular}{|l|c|c|}
\hline & Sayı & Yüzde \\
\hline Gerçek kișilerin bulunması & 6 & 7,8 \\
\hline Gerçek-çekimlerden olușması & 9 & 11,6 \\
\hline Tanıklık etmesi & 28 & 36,4 \\
\hline Gözleme dayalı olması & 15 & 19,5 \\
\hline Röportaja dayalı olması & 19 & 24,7 \\
\hline Toplam & 77 & 100 \\
\hline
\end{tabular}

Öğrencilere, "Bir belgeselin gerçeğe dayanması için aşağıdaki özelliklerden hangisi mutlaka bulunmalıdır?" sorusu sorulmuştur. Öğrencilerden \%36,4'ü "Tanıklık etmesi" seçeneğini işaretlemiştir. Bu sonuç, aynı zamanda "Öyküsünün gerçeğe dayanması" cevabıyla da ilişkilidir. Nitekim "Gerçek kişilerin bulunması" seçeneği, \%7,8 orandayken; "Gerçek-çekimlerden oluşması" \%11,6 oranda kalmaktadır. Bu bağlamda, belgeselin gerçekçilik savının, öyküleme biçimiyle ilişkili olduğu iddiası doğrulanmaktadır. Ayrıca, öğrencilerin \%24,7'si belgeselin gerçekliğini, geleneksel belgesellerin biçimsel özelliklerinden biri olarak gösterilen "Röportaja dayalı olması" ile ilişkilendirmektedir.

Tablo 5. İzlediğiniz Belgeseller, Sizde Gerçek-Dıșı Bir İzlenim Uyandırdı mı?

\begin{tabular}{|l|c|c|}
\hline & Sayı & Yüzde \\
\hline Evet & 29 & 37,7 \\
\hline Hayır & 48 & 62,3 \\
\hline Toplam & 77 & 100 \\
\hline
\end{tabular}

Tablo 6. İzlediğiniz Belgeseller, Canlandırmalar Yerine, Gerçek-Çekimlere Dayansaydı, Gerçekçilik Idddiaları Artar mıydı?

\begin{tabular}{|l|c|c|}
\hline & Sayı & Yüzde \\
\hline Evet & 31 & 40,3 \\
\hline Hayır & 46 & 59,7 \\
\hline Toplam & 77 & 100 \\
\hline
\end{tabular}

Gerçek-çekimlerle, belgeselin gerçekçilik savı arasında anlamlı bir ilişki kurmak adına, öğrencilere; "İzlediğiniz belgeseller, sizde gerçek-dışı bir izlenim uyandırdı mı?" sorusu sorulmuştur. Bu soruya, öğrencilerin \%37,7'si evet cevabını, \%62,3'ü ise hayır cevabını vermiştir. Bu sorudan sonra, anketin hipotezini doğrulamakadına öğrencilere, "İzlediğiniz belgeseller, canlandırmalar yerine, gerçek-çekimlere dayansaydı, gerçekçilik iddiaları artar mıydı?" sorusu sorulmuştur. Bu soruya da, öğrencilerin \%40,3'ü evet cevabını, \%59,7'si ise hayır cevabını vermiştir. Bu veriler doğrultusunda, gerçek-çekimlerle, belgeselin gerçekçilik savı arasında anlamlı bir ilişki olmadığı çıkarımına varılabilir. Çünkü belgeselde, gerçek-çekimler, buzdağının görünen kısmını sunmaktadır. Belgeselin biçimsel yapısı, bu yönelimde etkili olmaktadır. Ayrıca, buzdağının görünen 
kısmı kadar, görünmeyen tarafı da bir inceleme alanıdır. Örneğin, öyküleme biçimi, kurgu ve ses ile müzik kullanımı gibi anlatım yöntemleri de, gerçekçilik savı üzerinde etkilidir. Canlandırma belgesellerde bu yöntemler, gerçekçilik iddiasıyla yeniden inşa edilir.

Tablo 7. Verilen Cevapların Analizi

\begin{tabular}{|l|c|c|c|c|c|}
\hline & $\begin{array}{c}\text { Hiç } \\
\text { Katılmıorum }\end{array}$ & $\begin{array}{c}\text { Az } \\
\text { Katılıorum }\end{array}$ & $\begin{array}{c}\text { Orta Düzeyde } \\
\text { Katılıorum }\end{array}$ & $\begin{array}{c}\text { Cok } \\
\text { Katılıorum }\end{array}$ & $\begin{array}{c}\text { Tamamen } \\
\text { Katılıorum }\end{array}$ \\
\hline $\begin{array}{l}\text { Waltz With Bassir belgeselin } \\
\text { tüm özelliklerini içerir. }\end{array}$ & $1 \% 1,3$ & $8 \% 10,3$ & $27 \% 35,1$ & $26 \% 33,8$ & $25 \% 19,5$ \\
\hline $\begin{array}{l}\text { Is the Man Who Is Tall Happy?: } \\
\text { An Animated Conversation } \\
\text { with Noam Chomsky } \\
\text { belgeselin tüm özelliklerini } \\
\text { içerir. }\end{array}$ & $2 \% 2,5$ & $9 \% 11,7$ & $18 \% 23,4$ & $28 \% 36,4$ & $20 \% 26,0$ \\
\hline $\begin{array}{l}\text { The Life and Mind of Mark } \\
\text { DeFriest belgeselin tüm } \\
\text { özelliklerini içerir. }\end{array}$ & $9 \% 11,7$ & $17 \% 22,0$ & $19 \% 24,7$ & $14 \% 18,2$ & $18 \% 23,4$ \\
\hline $\begin{array}{l}\text { Filmleri değerlendirmemde } \\
\text { canlandırma kullanımının } \\
\text { katkısı vardır. }\end{array}$ & $17 \% 22,0$ & $21 \% 27,3$ & $15 \% 19,5$ & $14 \% 18,2$ & $10 \% 13,0$ \\
\hline $\begin{array}{l}\text { Canlandırma yöntemi belgesel } \\
\text { için uygun bir yöntemdir. }\end{array}$ & $11 \% 14,3$ & $15 \% 19,5$ & $12 \% 15,6$ & $23 \% 29,8$ & $16 \% 20,8$ \\
\hline
\end{tabular}

Anketin sonunda öğrencilerden üç filmi, belgesel türü açısından, beşli likert ölçeğinde değerlendirmeleri istenmiştir. "Waltz With Bassir belgeselin tüm özelliklerini içerir" sorusuna, öğrenciler \%53,3 oranında "çok katılıyorum + tamamen katılıyorum" cevabını vermiştir. Bu değerlendirmede, Waltz With Bassir'in öyküsünün, tarihe tanıklık eden ses kayıtlarından ve anılardan oluşması etkili olmuş olabilir. Nitekim filmin öyküsü, interaktif ve edimsel belgesellerin anlatım yöntemleriyle inşa edilmektedir.

"Is the Man Who Is Tall Happy?: An Animated Conversation with Noam Chomsky belgeselin tüm özelliklerini içerir" sorusuna, öğrenciler \%62,4 oranında "çok katılıyorum + tamamen katılıyorum" cevabını vermiştir. Bu sonuç, Is the Man Who Is Tall Happy?: An Animated Conversation with Noam Chomsky filminin, geleneksel belgesellerin biçimsel yapısına dayandırılmasıyla ilişkilendirilebilir. Örneğin, filmin anlatısı, interaktif belgesellerdeki gibi tamamen röportaj yöntemi ile inşa edilmektedir. Ayrıca filmin bir bölümünde, refleksif belgesellerdeki gibi filmin yapım süreçleri de gösterilmektedir. Filmin yönetmeni, filmin çekimlerinin yapıldığı kamerayı, çizim aşamalarını ve film yapım süreçlerini, canlandırma yöntemiyle betimlemektedir. Bununla birlikte, filmde, yönetmen Michel Gondry ve Noam Chomsky, öykünün tanıklıkları olarak gösterilmektedirler. Filmin öyküsü, bu iki kişinin karşılıklı konuşmasına dayanmaktadır. 
"The Life and Mind of Mark DeFriest belgeselin tüm özelliklerini içerir" sorusuna, öğrenciler \% 41,6 oranında "çok katılıyorum + tamamen katılıyorum" cevabını vermiştir. Öğrenciler, gerçek-çekimlere dayanan filmin, diğer iki filme kıyasla belgesel türe daha uzak olduğunu düşünmektedir. Bu sonuçta, filmin öyküleme biçimi etkili olmuş olabilir. Nitekim filmde, canlandırma görüntüler ile gerçek-çekimlerin, öykü içindeki inşası, birbirine zıt anlamlar oluşturmaktadır. Örneğin filmin bazı sahnelerinde, canlandırmalar mizahi bir anlatımla sunulurken; bu görüntülere gerçek-çekimler ve arşiv görüntüleri eşlik etmektedir.

Öğrencilerden izledikleri filmleri canlandırma ve belgesel bağlamında değerlendirmeleri istenmiştir. "Filmleri değerlendirmemde canlandırma kullanımının katkısı vardır" sorusuna, öğrenciler; \%49,3 oranında "hiç katılmıyorum + az katılıyorum" cevabını vermiştir. Buna karşın, "çok katılıyorum + tamamen katılıyorum" cevabının oranı \%31,2'dir. "Canlandırma yöntemi belgesel için uygun bir yöntemdir" sorusuna, öğrenciler, \%50,6 oranında "çok katılıyorum + tamamen katılıyorum" cevabını vermiştir. $\mathrm{Bu}$ sonuçta, filmlerde canlandırmaların, belgesel yöntemlerle temsil edilmesi etkili olmuş olabilir. Nitekim belgesel tarihindeki estetik, ideolojik ve teknolojik gelişmeler; belgeselin sınırlarının esnek olduğunu kanıtlamaktadır.

\section{Sonuc}

Belgeselde canlandırma ve gerçekçilik sorununun ele alındığı çalışmada, canlandırma belgesel türü incelenmiş ve canlandırma belgesellerin, geleneksel belgesellerle ilişkisi ortaya konmaya çalışıımıştır. Bu bağlamda, çalışmada anket çalışması yapıımış ve tür eleştirisi kapsamında veriler analiz edilmiştir. Tür eleştirisi, örneklem seçilen filmlerin anlatım yöntemlerini değerlendirmede ve araştırma hipotezlerinin oluşturulmasında yol gösterici olmuştur.

Çalışmada incelenen canlandırma yöntemi, belgeselin gerçekçilik savı için sorunlu gözükebilir. Çünkü belgeselin, gözlemlere dayanması, gerçekliğe tanıklık etmesi ve tarafsız olması gerektiği düşünülür. Bu düşünceden hareketle, anket çalışmasında, gerçek-çekimlerle belgeselin gerçekçilik savı arasında anlamlı bir ilişki olup olmadığına yönelik sorular sorulmuştur. Nitekim anket verilerine göre; gerçek-çekimlerle, belgeselin gerçekçilik savı arasında anlamlı bir ilişki olmadığı sonucuna varılmaktadır. Anket verilerine göre; belgeselin gerçekçilik savında öyküleme biçimi etkili olmaktadır. Çalışmanın ikinci hipotezini, belgeselin biçimsel özellikleri ile türe ait özellikler arasında anlamlı bir ilişki olduğu varsayımı oluşturmaktır. Bu nedenle, canlandırma yöntemi ve belgeselin biçimsel yapısı arasında bir ilişki kurulmaya çalışılmıştır. Nitekim canlandırma belgesel türünün, belgesele ait bir tür olup olmadığı, halen tartışma konusudur. Bu bağlamda çalışmada, öğrencilere üç film izlettirilmiş ve belgesel kapsamında değerlendirmeleri istenmiştir. Öğrenciler, belgeselin biçimsel özelliklerini içeren ve canlandırma yöntemine dayanan, Waltz With Bassir ve Is the Man Who Is Tall Happy?: An Animated Conversation with Noam Chomsky filmlerini, belgesel kapsamında değerlendirmektedirler. Röportaj kayıtlarının canlandırıldığı Is the Man Who Is Tall Happy?: An Animated Conversation with Noam Chomsky filmi, \%62,4 oranında en yüksek oranda değerlendirilmiştir. Diğer iki örneğe kıyasla, ağırlıklı olarak gerçek-çekimlere dayanan The Life and Mind of Mark DeFriest filmi, \%41,6 oranında belgesel kapsamında değerlendirilmiştir. 
$\mathrm{Bu}$ verilerden ve Andre Bazin ile Siegfried Kracauer'in yaklaşımlarından hareketle, canlandırma belgesel türü; belgeselde oluşan bir dil arayışı olarak ele alınabilir. Nitekim Andre Bazin, sinemasal gerçekliği, gerçeğin tamamlayıçsı olan estetik uygulamalarla ilişkilendirmektedir. Siegfried Kracauer ise sinemayı fotoğraf ile ilişkilendirmektedir. Canlandırma yöntemi, fotoğrafik gerçeklikle zıt kutuplarda yer almaktadır. Ancak, günümüzde fotoğrafik görüntünün hipergerçek bir görünüm kazandığı iddia edilebilir. Nitekim gündelik yaşamda gerçeklik, sanal bir görünüme dönüşmektedir. Yeni iletişim teknolojileri, her şeye sanal, dokunmatik ve sayısal bir gerçeklik kazandırmıştır. Örneğin, sosyal medyada, bireyler, gündelik faaliyetlerini ve gündelik gerçekliklerini, en doğal halleriyle belgelemektedirler.

Nitekim belgesel sinemada da, gerçekliğin sunumunda arayışlar oluşmaktadır. Örneğin, her yıl belgesel festivallerinde ${ }^{59}$, pek çok canlandırma belgesel gösterilmekte ve ödül almaktadır. Canlandırma belgesel türü, içerik olarak zaman zaman geleneksel belgeselden uzaklaşmış gibi görünebilir. Çünkü canlandırma belgesellerde, gerçek ile gerçek-dışılık bir arada sunulur; ancak bu filmlerde gerçekçilik iddiası, belgesel yöntemlerle dengelenmektedir. Bu bağlamda, canlandırma belgesellerin melez bir tür veya sahte-belgesel olup olmadığı sorunu yerine; belgeselde temsil ettikleri tasarım ve gerçekçilik boyutu sorgulanmalıdır.

\section{Kaynakça}

Abisel, Nilgün. (2003). Sessiz Sinema. İstanbul: Om.

Adalı, Bilgin. (1986). Belgesel Sinema. Ankara: Hil.

Adanır, Oğuz. (2010). Baudrillard. İstanbul: Say.

Akbulut, Durmuş.(2012). Belgesel ve Deneysel Sinema. İstanbul: Etik.

Andrew. J. Dudley. (2010). Büyük Sinema Kuramları. Zahit Atam (çev.). İstanbul: Doruk.

Bazin, Andre. (1966). Çağdaş Sinemanın Sorunları. Nijat Özön (çev.). Ankara: Bilgi.

Bazin, Andre. (2011). Sinema Nedir?. İbrahim Şener (çev.). İstanbul: Doruk.

Betton, Gerard. (1993). Sinema Tarihi: Başlangıcından 1986'ya kadar. Şirin Tekeli (çev.). İstanbul: İletişim.

Bordwell David ve Thompson Kristin. (2012). Film Sanatı. Ertan Yılmaz ve Emrah Suat Onat (çev.). Ankara: De-Ki.

Buckland, Warren. (2010). Sinemayı Anlamak. Mutlu Dinçer (çev.). İstanbul: Optimist.

Clarke, James. (2012). Sinema Akımları: Sinema Dünyasını Değiştiren Filmler. Çağdaş Eylem Babaoğlu (çev.). İstanbul: Kalkedon.

59 Bkz. https://animateddocs.wordpress.com/category/festivals/ ve http://www.documentary.org/magazine/ when-docs-get-graphic-animation-meets-actuality 12.02.2016. 
Demoğlu, Elif. (2010). "Kültür Endüstrisi ve Gerçeğin Sinemada Yön Değiştirmesi: Sahte Belgesel". Hakan Aytekin (der.) içinde. Belgesel Sinema 2010. İstanbul: BSB Sinema Eseri Sahipleri Meslek Birliği. 33-41.

Frisby, David. (2012). Modernlik Fragmanları: Simmel, Kracauer ve Benjamin'in Eserlerinde Modernlik Teorileri. Akın Terzi (çev.). İstanbul: Metis.

Kracauer, Siegfried. (2014) Tarih Sondan Bir Önceki Şeyler. Tuncay Birkan (çev.). İstanbul: Metis.

Mclane. Betsy. A. (2012). A New History of Documentary Film. London: Continuum.

Monaco, James. (2010). Bir Film Nasıl Okunur?. Ertan Yılmaz (çev.). İstanbul: Oğlak.

Musser, Charles. (2008). "Gerçeğe Tutunmak". Dünya Sinema Tarihi. Geoffrey Nowell Smith (ed.) içinde. Ahmet Fethi (çev.). İstanbul: Kabalcı. 377-385.

Nochimson, P. Martha. (2013). Bir Dünya Sinema. Özgür Yaren (çev.). 1.Baskı. Ankara: De-ki.

Onaran, Alim, Şerif. (1999). Sinemaya Giriş. 2. Baskı. İstanbul: T.C. Maltepe Üniversitesi.

Özarslan, Zeynep. (2013). "Siegfried Kracauer". Sinema Kuramları 1. Zeynep Özaslan (ed.) içinde. İstanbul: Su. 185-220.

Özarslan, Zeynep. (2013). "Sinemada Tür Kuramı". Sinema Kuramları 2. Zeynep Özaslan (ed.) içinde. İstanbul: Su. 51-75.

Özden, Zafer. (2014). Film Eleştirisi: Film Eleştirisinde Temel Yaklaşımlar ve Tür Filmi Eleştirisi. Ankara: Imge.

Özön, Nijat. (1981). Sinema Ve Televizyon Terimleri Sözlüğü. Ankara: Türk Dil Kurumu.

Özön, Nijat. (2010). Sinemaya Giriş. İstanbul: Agora.

Roe, Honess, Annabelle. (2011). "Uncanny Indexes: Rotoshopped Interviews as Documentary". Animation: An Interdisciplinary Journal. 7(1):25-37. http://anm.sagepub.com/content/7/1/25, 02.02. 2016.

Roe, Honess, Annabelle. (2011). "Absence, Excess and Epistemological Expansion: Towards a Framework for the Study of Animated Documentary". Animation: An Interdisciplinary Journal. 6(3): 215-230. http://anm.sagepub.com/content/6/3/215, 02.02.2016.

Roe, Honess, Annabelle. (2013). Animated Documentary. Basingstoke, Hampshire and New York: Palgrave Macmillan.

Rosenthal, Alan. (2002). Writing, Directing and Producing Documentary Films and Videos. Third Edition. Southern Illinois: University.

Rotha, Paul. (2000). Belgesel Sinema. İbrahim Şener (çev.). İstanbul: İzdüşüm. 
Saunders, Dave (2014). Belgesel. Ali Nejat Kanıyaş (çev.). İstanbul: Kolektif.

Sheila, Sofian. (2005). Fps Magazine: Frames per second magazine. The Truth in Pictures. Second Volume, Issue (1). 7-11.

Song, Miao. (2009). The Role of Computer Graphics in Documentary Film Production. April. Canada: Concordia University. 3-10.

Susar, A, Filiz. (2004). Türkiye'de Belgesel Sinemacılar. İstanbul: Es.

Şenler, Filiz. (2005). "Animasyon Tarihi, Teknikleri ve Türkiye'deki Yansımaları". Türkiyat Araştırmaları. Hacettepe Üniversitesi. Sayı (3): 99-114. http://turkoloji.cu.edu.tr/GENEL/filiz senler_animasyon_tarihi.pdf 05.02.2016.

Topçu, Y, Gürhan. (2013). "Saf Sinemaya Dönüş Denemesi: Dogma 95", Sinema Kuramları 2. Zeynep Özaslan (ed.) içinde. İstanbul: Su. 193-220.

Ünal, T, Gülin. (2010). "Sinemada Estetik Kaygı Ve Anlatım Aracı Olarak Sinema Tekniği". İri, Murat. (der.) içinde. Sinema Araştırmaları: Kuramlar, Kavramlar, Yaklaşımlar. İstanbul: Derin. 7-23.

http://defriest.com/ 04.02.2016.

https://thedissolve.com/reviews/385-is-the-man-who-is-tall-happy-an-animated-conversat/ 12.08.2015.

http://waltzwithbashir.com/film.html 12.04.2015. 